DOI https://doi.org/10.30525/978-9934-26-110-7-24

\title{
МИСТЕЦЬКИЙ УКРАЇНСЬКИЙ РУХ ЯК ФЕНОМЕН ЛІТЕРАТУРНОГО ВІДРОДЖЕННЯ
}

\author{
Юрчак Г. М. \\ кандидат філологічних наук, доцент, \\ дочент кафедри мовознавства \\ Івано-Франківський начіональний медичний університет \\ м. Івано-Франківськ, Украӥна
}

Період української літератури 20-их років ХХ століття характеризується як кризовий не лише в межах Радянського Союзу, що було очевидним, оскільки література, витворена внаслідок одногранних кліше та стереотипів, не могла функціонувати як національно ідентична, але й за кордоном. Щоправда, поняття кризи в цьому випадку було дисемантичним. Це пояснюється тим, що в рамках обмеженого простору СРСР криза української літератури існувала внаслідок підпорядкованості політиці, що породжувало протизахідний ізоляціонізм, тому й була неминуча. Інша криза української літератури пояснюється тим, що мистецтво, зокрема українське, не віднаходило себе у світовому контексті, що інколи був занадто складним для нього.

Слушно зауважує Соломія Павличко, що «не всім вистачило сміливості говорити про стан речей прямо, не всім вистачило його розуміння, але навіть у риториці наймажорніших виступів ховався страх перед об'єктивною історичною ситуацією й відповідно страх майбутнього - свого зокрема і майбутнього української літератури в цілому. Слова, однак, народжуються «високі», а перспективи змальовувались песимістично» [3, с. 284].

Унікальним явищем в історії української літератури XX ст. була поява української літератури в еміграції, за межами рідної землі письменники мали можливість творити так, як відчували. Варто відзначити працю Л. Стефановської, яка в антології першоджерел «Misson Imposible. МУР і відродження українського літературного життя у таборах для біженців на території Німеччини 1945-1948» згадує про цей період відродження. Власне на чужині ствоювалася українська література, виникла потреба в колективному обговоренні написаного, рецензуванні та виданні творів, з'явився читацький арсенал, що прагнув якісно нових речей. Так у 1945 р було створено МУР (Мистецький український рух). 
МУР $з$ перших кроків почав сприйматись як чергове відродження. Основним завданням письменників було творити якісну літературу. Щоправда, погодьмося із думкою багатьох науковців, що багато письменників принесли із собою кліше й стереотипи радянської, так званої неонародницької літератури та критики, котрих, як виявилося, не так легко було позбутися. Очевидно й тому, що із самого початку мурівський дискурс був глибоко конфліктним. У ньому відродилися старі суперечки й дилеми української літератури, оскільки естетичний рух європейського модернізму зіткнувся із спротивом носіїв радянських шаблонів письма. Пошук національного став на порядку денному у відповідь на вимогу інтернаціоналізму, пошук світового звучання став відповіддю на радянську колоніальну політику провінціалізації української літератури.

Концепція «великої літератури» У. Самчука полягала в тому, що українська література повинна була усвідомити своє національновизвольне надзавдання, звернутись у своєму широкому масштабі до класики. Власне слушну думку висловив Іван Багряний, який вважав, що «велика література» - це «література національна за своїм духом, тобто пронизана великою українською ідейністю, оптимістична, життєрадісна, самостверджувальна» [2, с. 4].

Ю. Косач як один із засновників організації неодноразово виступав на з’їздах МУРу, публікував статті в його збірниках, продукував ідеї, а також розроблив концепцію розвитку української літератури, суть якої полягала в тому, що література повинна розвиватися вільно. Відтак література Заходу стала ідеалом модерності, взірцем справжньої літератури. Юрій Косач був впевненим, що література повинна бути втіленням мистецької правди, ідеї гуманізму стали надважливими. Письменник акцентував на суверенності письменника, який повинен висловлювати власну думку, реагувати на події, однак повинен бути незалежним від інших і творити лише те, чого вимагає його творча сила [4, с. 39]. Юрій Косач пише, що твір письменника - це «наслідок боротьби; $з$ демоном чи янголом, як хто хоче; боротьби запеклої, страшної, де проти письменника - сировинний матеріал життя, необтесана брила, іiї опір, а за нього - його талант, інтуїція, чуття, розум, культура, філософічний світогляд і праця» [1, с. 56]. Автор зазначає, що велика модерна література може існувати лише там, де є свобода письменника.

Творчість Ю. Косача нерозривно пов'язана $з$ діяльністю МУРу, його основними стильовими тенденціями, «еміграційним ренесансом», під час якого питання модернізації, як стверджує С. Павличко, було ключовим. 
Упродовж трьох років існування цієї організації мурівці намагалися збагнути, якою має бути українська література, аби вона посіла гідне місце у світі. Уже на першому з'їзді МУРу Ю. Косач виголосив промову «Вільна українська література», де заявив, що письменникам заборонено мовчати, як би це парадоксально не звучало, навіть тоді, коли їхні погляди не знаходять підтримки в суспільстві. «Творчий імпульс письменника - це його свобода» [1, с. 59], не варто засуджувати його, потрібно, як уважає Юрій Косач, уміти вислухати та висловити свої думки, бо «велика література існує тільки тоді, коли $\epsilon$ про що й $є$ кому дискутувати» [1, с. 58].

Отже, значення МУРу як широкомасштабного дискурсу вагоме.

По-перше, це було вдалою спробою згуртувати талановите українське суспільство за межами рідної землі, створити для своєї праці спільне ідеологічне підгрунтя. Звісно, на материковій Україні в той час існували різні угруповання, здобутки яких не особливо рясніли вартісними творами. Це було очевидним, оскільки меценатами таких творів ставали політики, які «диктували» ідеї для художніх творів, тобто було створено художні твори «на замовлення» тоталітарної влади. Про самодостатність такого письма, тим більше про його художню вартість, не було й мови.

По-друге, мурівці зробили все можливе, щоб література перестала бути «прислугою» політики. Вони змогли своїми високо художніми творами європейського рівня здобути для неї світове визнання лише через неповторну та органічну своєрідність українського письменства.

По-третє, МУР зумів організувати видання творів, адже за кілька років у таборах було видрукувано більше 1200 книг.

\section{Література:}

1. Косач Ю. Вільна українська література. МУР. 1946. № 2. С. 47-65.

2. Лисенко-Ковальова Н. Мистецький український рух: модернізація літературної традиції і модернізм: Автореф. дис... канд. філол. наук: 10.01.01 НАН України. Ін-т л-ри ім. Т.Г.Шевченка. Київ, 2006. 19 с.

3. Павличко С. Дискурс модернізму в українській літературі : монографія. 2 ге вид., перероб. і доп. Київ : Либідь, 1999. 447 с.

4. Юрчак Г.М. Жанрово-стильова своєрідність романістики Юрія Косача : автореф. дис. ... канд. філол. наук : 10.01 .01 / ДВНЗ «Прикарпатський національний університет імені Василя Стефаника». Івано-Франківськ, 2018. 20 с. 